\title{
The intermediate Mediterranean water inflow along the northern slope of the Iberian Peninsula
}

\author{
Guillermo DÍAZ del RÍO*, Nicolás GONZÁLEZ, David MARCOTE
}

Instituto Español de Oceanografía, Centro Oceanográfico de La Coruña, Apdo. 130, La Coruña, Spain

(Revised 19/12/97, accepted 28/01/98)

\begin{abstract}
During the SEFOS 95 cruise (25 March to 15 April 1995) (figure 1) a number of CTD casts were made in order to study the internediate Mediterranean water (IMW) off the west and north coasts of the Iberian Peninsula. One long-term mooring, for current measurement at four levels, was deployed at $43^{\circ} 57^{\prime} \mathrm{N}-5^{\circ} 51^{\prime} \mathrm{W}$ from February to May. We establish a picture of the distribution and transformation of the IMW along the coast of the Iberian Peninsula based on the thermohaline characteristics of the water masses and the determination of the percentage content of the IMW by the use of the triangle of vertical mixing of the North Atlantic central water (NACW), IMW and Labrador water (LW) [3]. A generalised temperature/salinity (T/S) curve is plotted (figure 6) on the basis of the T/S curves of the cruise. The results of 3 months' current measurements are shown. (C) Elsevier, Paris
\end{abstract}

\section{water mass / North Atlantic central water / intermediate Mediterranean water / Labrador water / salinity}

Résumé - Flux d'eau intermédiaire méditerranéenne le long de la pente continentale au nord de la péninsule ibérique. L'eau intermédiaire méditerranéenne a été étudiée à l'ouest et au nord de la péninsule ibérique pendant la campagne SEFOS 95 (2.5 mars-15 avril 1995). Les courants ont été enregistrés à quatre profondeurs, de février à mai, par $43^{\circ} 57^{\prime} \mathrm{N}-5^{\circ} 51^{\prime} \mathrm{W}$. Le schéma de répartition et d'évolution de l'eau intermédiaire méditerranéenne a été établi à partir des caractéristiques hydrologiques des eaux ; ses proportions ont été déterminées à l'aide du triangle de mélange vertical des trois eaux : eau centrale nord-atlantique, eau intermédiaire méditerranéenne et eau du Labrador. Un diagramme TS généralisé est établi à partir des courbes TS de la campagne. Les résullals de trois mois de courantométrie sont présentés. (C) Elsevier, Paris

masse d'eau / eau centrale nord-atlantique / eau intermédiaire méditerranéenne / eau du Labrador / salinité

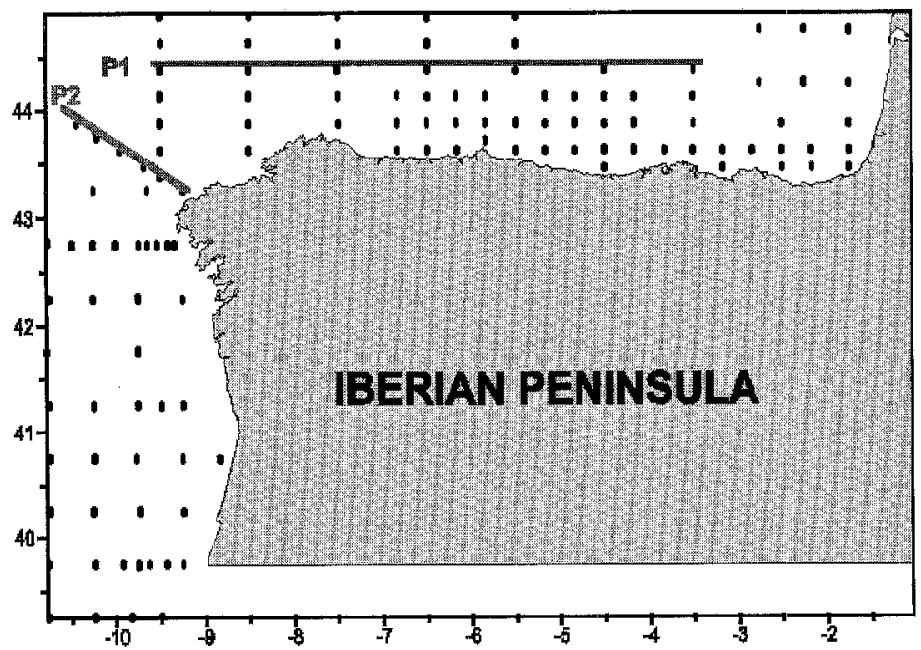

Figure 1. Situation of stations in the SEFOS-95 cruise.

* Correspondence and reprints: 

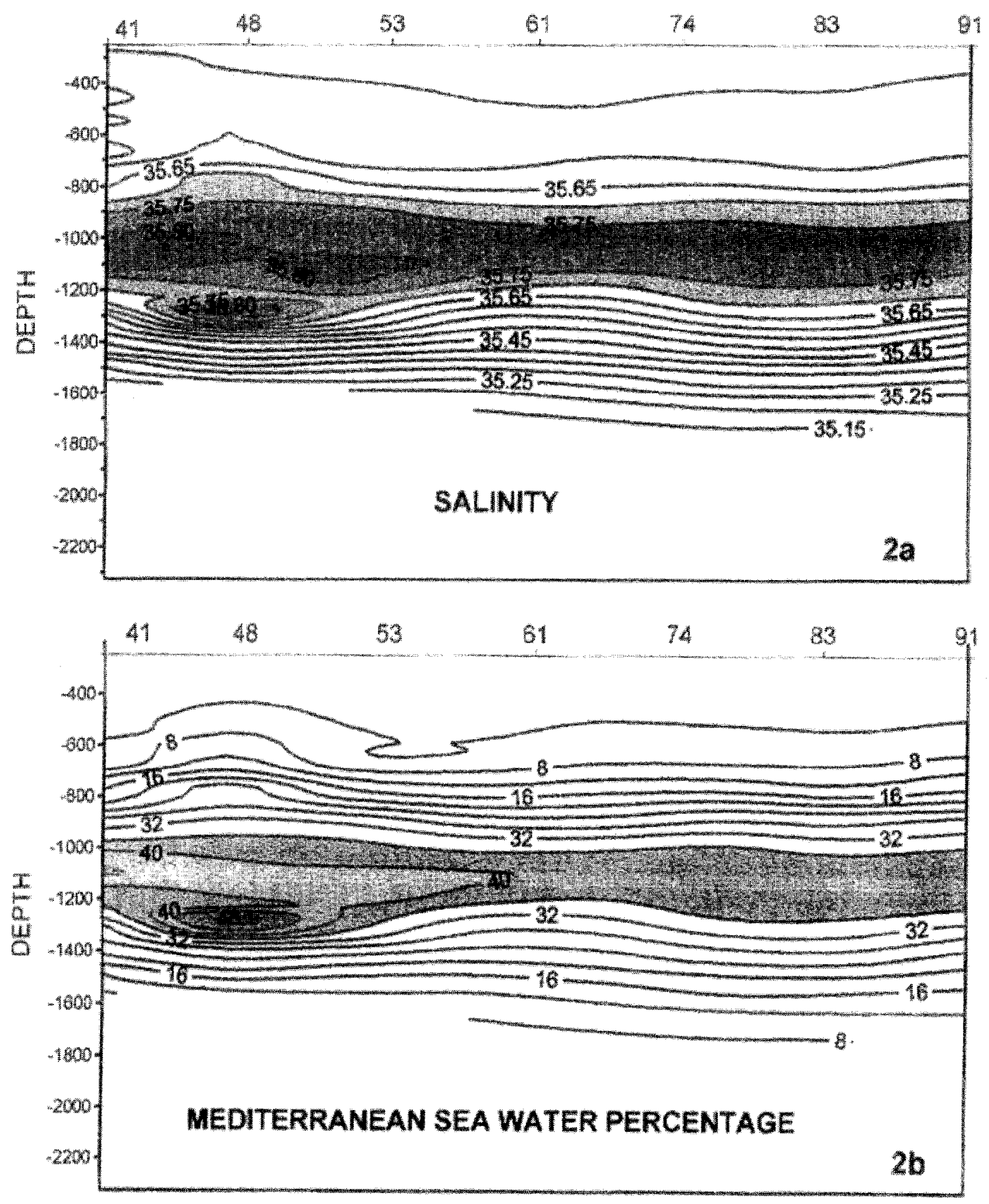

Figure 2. Sections of salinity distribution on seven stations for profile Pl (2a) and the percentage content of intermediate Mediterranean water (IMW) (2b). In both $2 \mathrm{a}$ and b, regions where the water mass salinity exceeds 35.7 or $36 \%$ of IMW mass are shaded. These shaded areas show that the density of the intermediate water mass does not change, in spite of the decrease in salinity to the east, and that off Galicia there is a splitting of the IMW core due to an increase in density in the lower part of the core. 

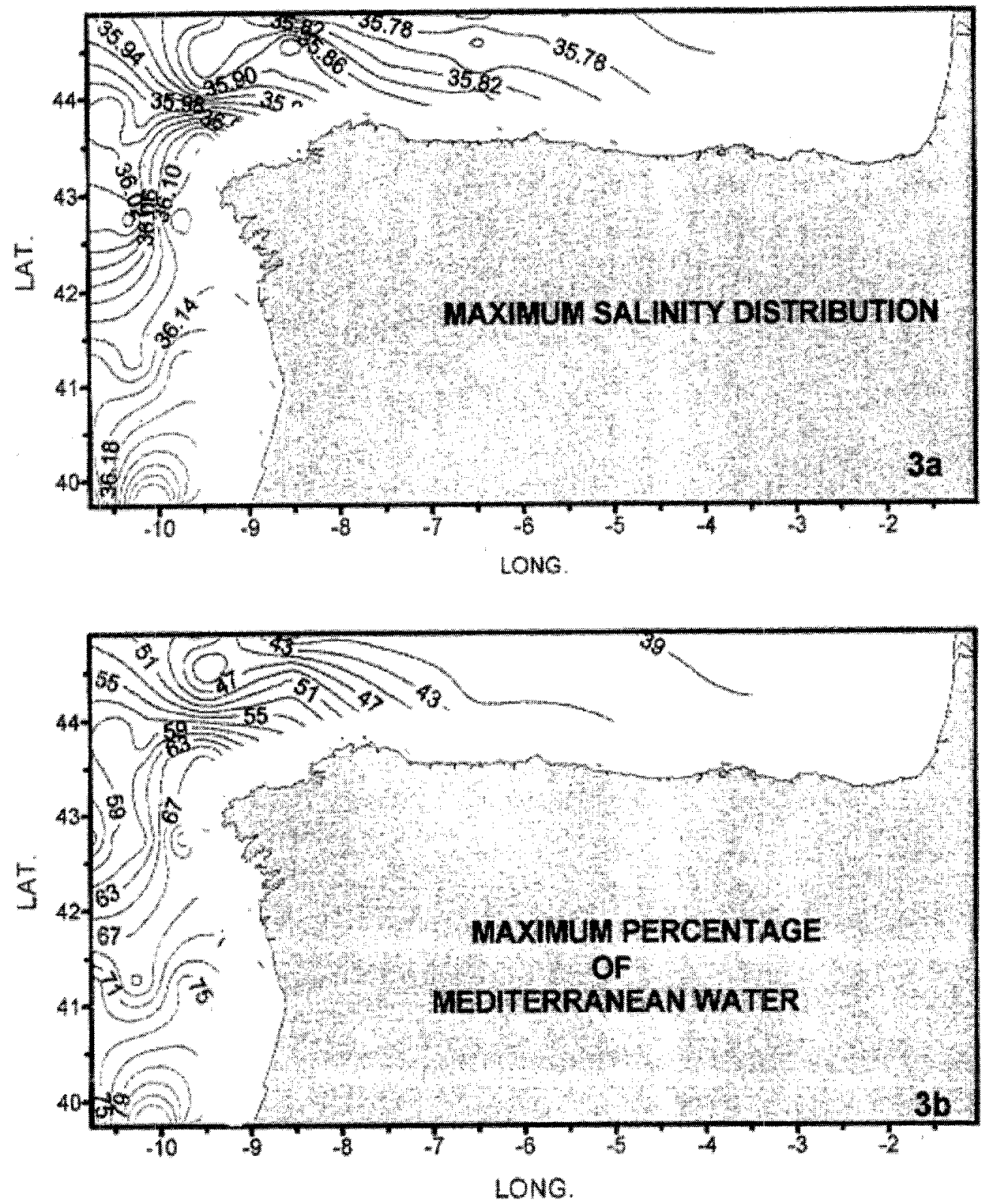

Figure 3. Horizontal sections of the maximum salinity distribution (3a) and maximum percentage content of intermediate Mediterranean water (IMW) (3b), showing that the nucleus of the IMW changes from salinity 36.2 and $78 \%$ of IMW off Portugal to 35.76 and $39 \%$ of IMW in the inncr area of the Bay of Biscay, and how this flow is mainly a coastal process. 

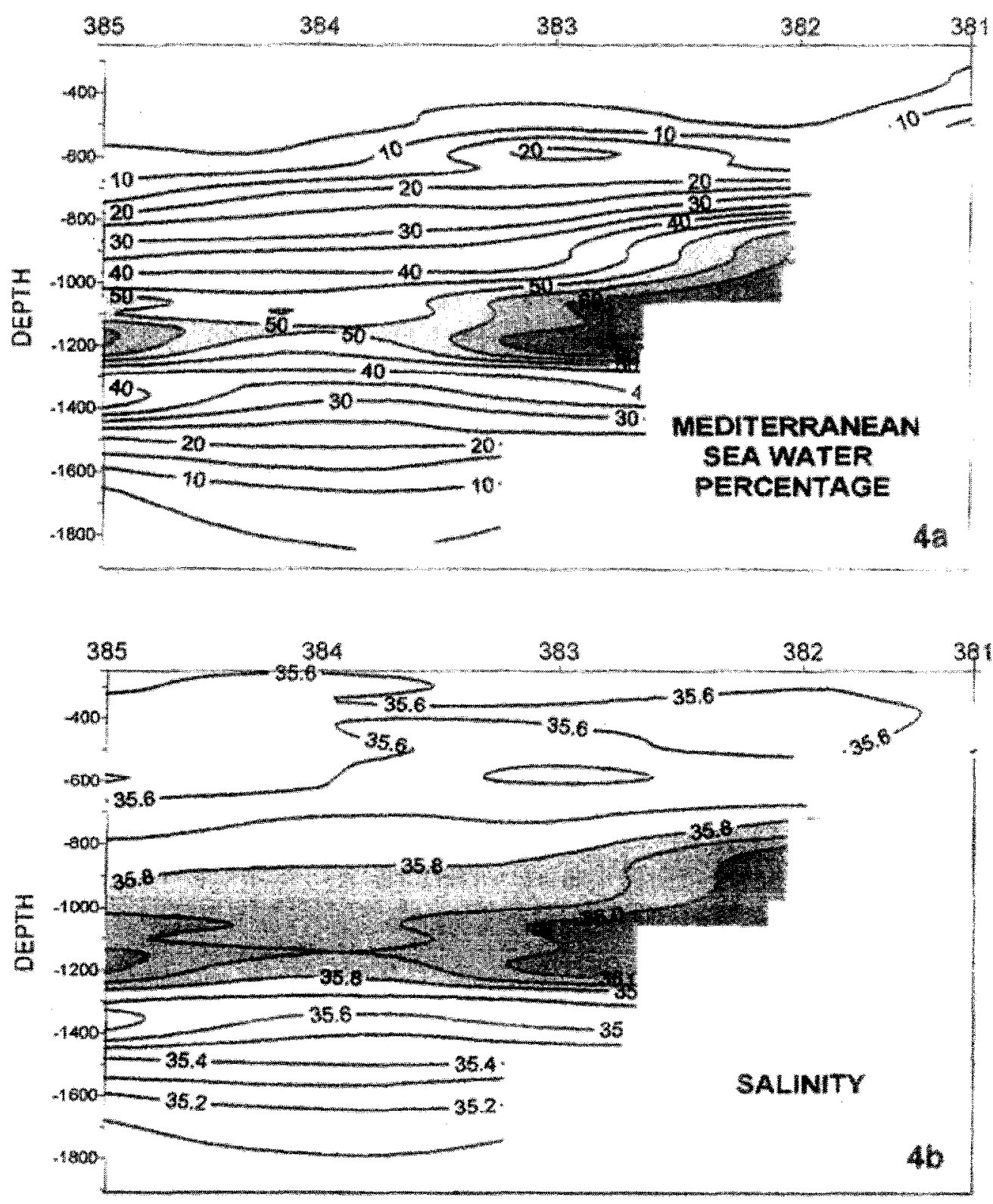

Figure 4. Sections of salinity distribution off Cape Finisterre (4a) and the percentage content of intermediate Mediterranean water (IMW) ( $4 \mathrm{~b}$ ) for profile P2, from stations 385 to 381 . Regions where the salinity exceeds 35.8 or where IMW accounts for more than $50 \%$ of the water mass are shaded, showing the strong influence that the IMW can exert in this oceanic area: at the slope a great part of the core rises to almost $800 \mathrm{~m}$ depth, while another nucleus splits from the main core into the ocean. 

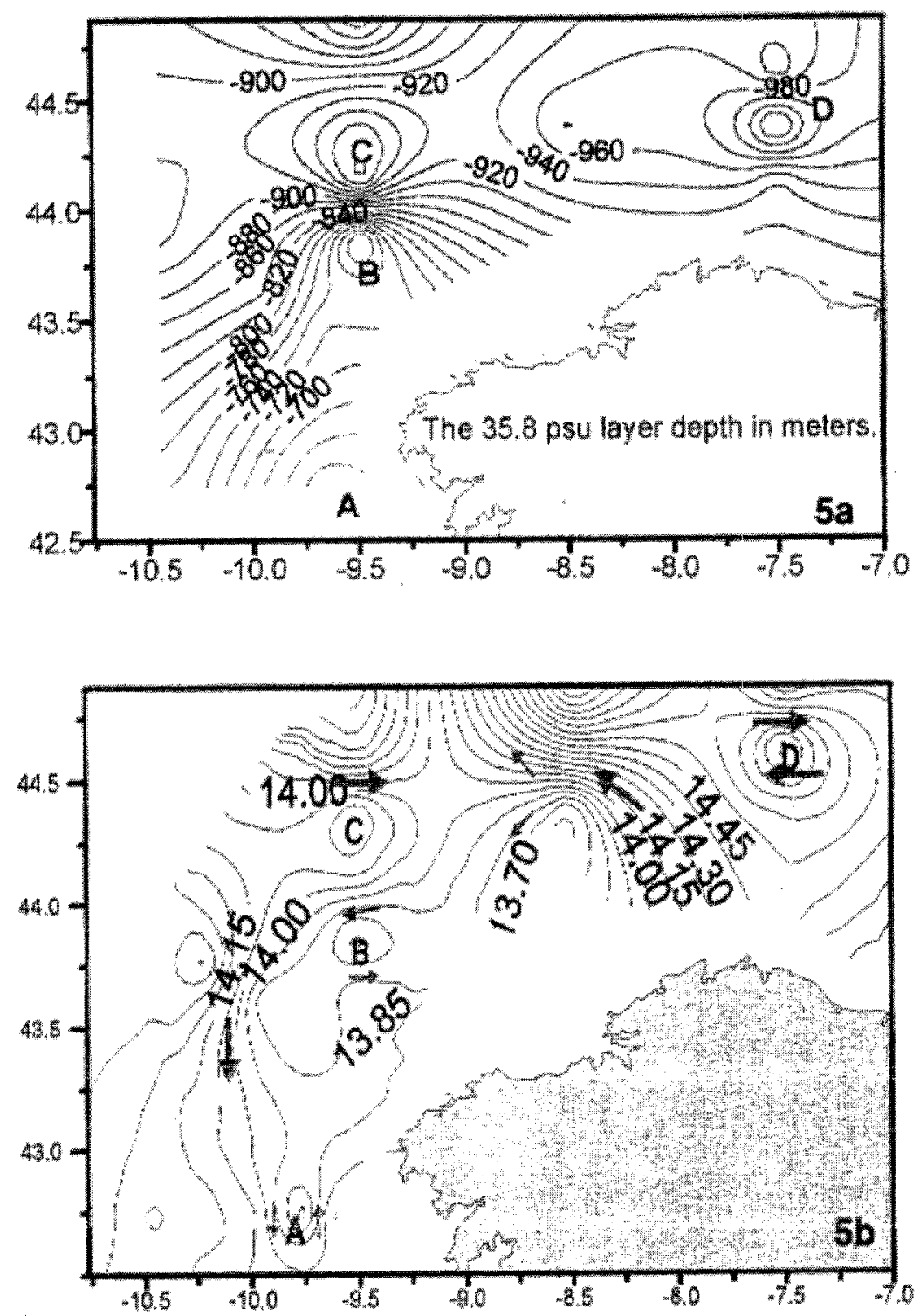

Figure 5. Layer of the upper level of salinity 35.8 (5a) and the dynamic height difference, at $300 \mathrm{dbar}$ reference surface $600 \mathrm{dbar}(5 \mathrm{~b})$. They show a strong correlation, suggesting a significant influence of the intermediate Mediterranean water (IMW) core on the dynamic of the North Atlantic central water (NACW). Points A and B in both 5a and b are related to the rise of the 35.8 surface and the descent of the dynamic height, while points $\mathrm{C}$ and $\mathrm{D}$ are related to the sinking of the 35.8 surface and the rise of the geopotential anomaly. Therefore, off Cape Finisterre the fluctuating vein of salty water (IMW) turning to the west below the frontal area of convergence with the anticyclonic gyre in the Bay of Biscay could generate strong anti-clockwise eddies in the NACW. 


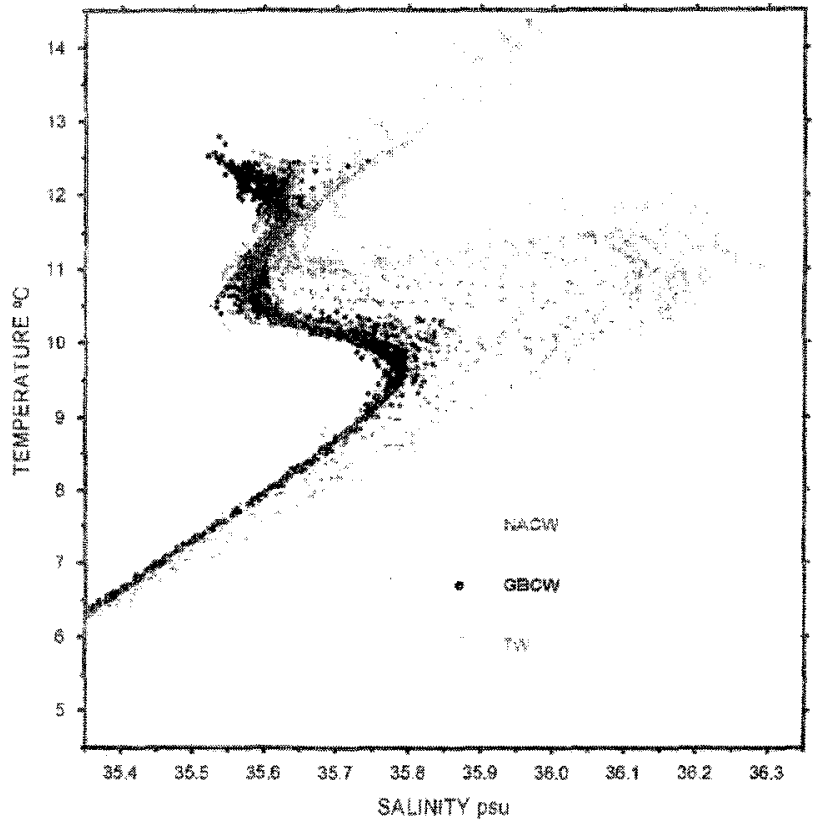

Figure 6. Generalised temperature/salinity (T/S) curves plotted on the basis of the T/S of the cruise in North Atlantic central water (NACW), Gulf of Biscay central water (GBCW) [2] and transition water (TW) [1, 2].

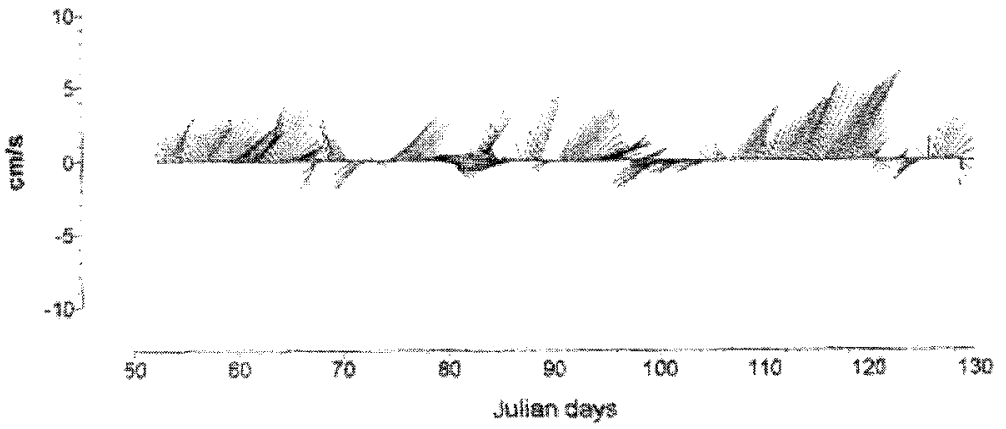

$17 \mathrm{a}$

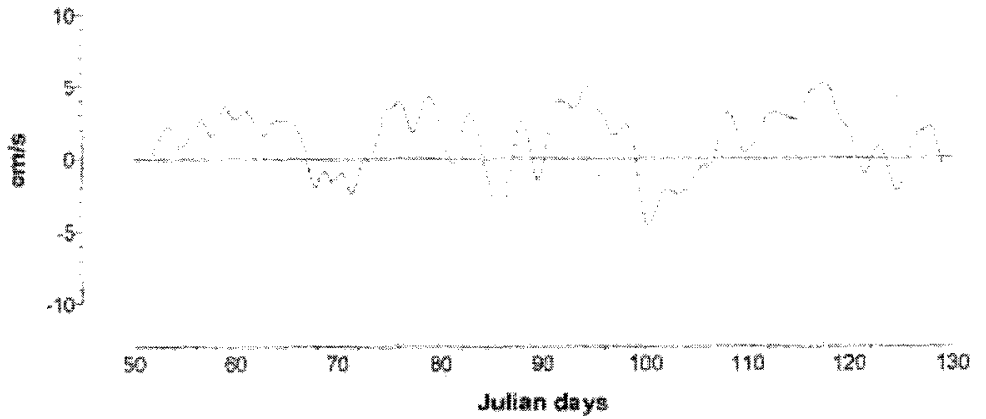

\section{$(7 \mathrm{~b})$}

Figure 7. Current measurement at $1000 \mathrm{~m}$ depth (7a) velocity vector and (7b) east-west component. The series of dates have been smoothed by means of a Godin $\mathrm{A} 2 \mathrm{~A} 2 \mathrm{~A} 3$ filter to eliminate the high frequency noise. The low frequency oscillations have been obtained applying a Godin A24A24A25 filter. 


\section{CONCLUSIONS}

It is well known that the intermediate Mediterranean water (IMW) mass flowing from the Strait of Gibraltar into the North Atlantic sinks to $1200 \mathrm{~m}$ and flows mainly to the north along the west coast of the Iberian Peninsula.

Oाf Cape Finisterre this lluctuating vein of sally water turns to the east (figure 3), into the Bay of Biscay, south of the frontal area of convergence with the anticyclonic gyre.

Its thermohaline characteristics allow us to follow the water mass corresponding to the IMW core and to map its geographical distribution and path of propagation (figures 2 and 4).
From the sections of dynamic height difference (300600 dbar) and upper level of salinity 35.8 (figure 5), it is suggested that this flow of salty deep water could have a strong influence on the North Atlantic central water (NACW).

The large increase in density of the IMW core off Galicia (figure 2) can only be explained by the process of contraction on mixing with the Labrador water (LW). The current measurement at $1000 \mathrm{~m}$ depth (figure 7) shows a predominant flow to the east, with sporadic inversions, supporting the idea of a fluctuating flow of IMW.

\section{REFERENCES}

[1] Fraga F., Upwelling off the Galician coast, northwest Spain, in: Richards F.A. (Ed.), Coastal Upwelling, Coastal Estuarine Sci., vol. 1, AGU, Washington D.C, 1981, pp.176-182.

[2] Fraga F. et al., Las masas de agua en la costa de Galicia: juniooctubre, Res. Exp. Cient. 10 (1982) 51-57.
[3] Mamayev O.I., Temperature salinity analysis of world ocean waters, in: Elsevier Oceanography series, vol. 11, Elsevier Scientific Publishing Co., Amsterdam-Oxford-New York, 1975. 